\title{
Licia's Temple: Giles Fletcher the Elder and Number Symbolism
}

\author{
ANNE LAKE PRESCOTT
}

S cal patterning in Renaissance verse is clouded not only by "obscurantist" opposition but by "sciolist" support. ${ }^{1}$ It is hard to disagree. Like collecting UFOs, counting things can become an obsession, and while the resulting hallucinations probably don't do much harm they may render more solid structures difficult to distinguish. At the risk of joining the crowd of those who lisp in numbers, however, I would like to propose that Giles Fletcher's Licia offers an intriguing example of numerical patterning and, moreover, that it does so in ways which anticipate Spenser's far more subtle and complex architecture.

Briefly, I think it can be shown that the fifty-two sonnets in Licia form a calendar in which the lady herself is closely associated with the sun and its passage through the days, weeks, and seasons of the year. One can even, I think, date the calendar. The preface is signed September 1593, and if Fletcher's modern editor is right in supposing that the poems were written after 1591 , then the sequence could correspond to $1592 .^{2}$ The poems which follow the sonnets may in turn reiterate this annual voyage, but if so they wheel through a different pattern and point to a different conclusion. Fletcher's witty introduction both warns against overinterpretation and effectively invites such speculation. Who, he asks teasingly, is the object of his worship? Certainly his chaste goddess is not fired by base lust. In fact she is possibly allegorical - she could be Learning, for instance, or Discipline, "some heavenlie woonder," the courtesy of his patroness, or even a college.

The well-crafted if unexciting poems which follow this disingenuously charming preface are less original in flavour. When Fletcher looked in his heart to write he usually saw not the image of his lady (or college) but a number of Neo-Latin poets and Ronsard. Not surprisingly, therefore, the speaker's adventures in passion and celebration look familiar. He begins by recounting how he wanted to write verse and how despite Phoebus' coldness he was enabled to do so by Venus' welcome. Licia 
herself, of course, is usually reluctant, for unlike Spenser but like almost everybody else, Fletcher was more inspired by denial than by acquiescence; even after a few poems free from the usual discomforts of fire, ice, anxiety, and disintegration, the sequence ends with no assurance of victory. No wonder that the lover hurts so badly. Licia is his light, keeper of his heart, guide to his soul, epitome of treasure. She burns his poems and ignores his sighs, but she frightens him into generosity with her illness, calms the seas, kindles the waves, and rejoices the sun. She sometimes kisses him into ecstasy, once comes to him in a dream all naked and willing, and plunges him into darkness by her absence.

The poems themselves, then, go through predictable motions; but Fletcher organises these conventional complaints, pleas, and encomia into a structure plausibly compared to the temple his opening poem says he will build, and as he does so he associates Licia with solar radiance and hence with poetry itself. Even the name "Licia" suggests effulgence, for it derives from the Greek for "light" - and some of Fletcher's readers might have recollected that the Asian country of Lycia was the location of one of Apollo's oracles.

A prefatory sonnet to this luminescent figure, unnumbered and evidently standing outside the sequence proper, hints at what the following poems will contain. Note both the claim that the poet builds a temple and the immediate connection between Licia and the sun:

Bright matchles starre, the honour of the skie,

From whose cleare shine, heavens vawt hath all his light,

I send these Poems to your gracefull eye:

Doe you but take them, and they have their right.

I build besides a Temple to your name,

Wherein my thoughts shall daily sing your praise:

And will erect an aulter for the same,

Which shall your vertues, and your honour raise.

But heaven the Temple of your honour is,

Whose brasen toppes your worthie selfe made proude:

The ground an aulter, base for such a blisse

With pitie torne, because I sigh'd so loude.

And since my skill no worship can impart,

Make you an incense of my loving heart.

The numerical pattern of the poems which follow is at first glance quite obvious, although certain refinements appear after a little calculation. There is an extra (and unnumbered) sonnet, to be sure, upon the daughters of Fletcher's patroness Lady Molineux, and I cannot account for its presence, but there are clearly fifty-two numbered sonnets to Jicia. Needless to say, these recall the weeks and thus tie the lover's feelings to the rotation of the year. But apparently Fletcher wanted to 
go further. In the prefatory sonnet he had said he would worship "daily." What of the days, then? Fifty-two weeks will not give the right number of them, so an extra day must be found. Now, if each sonnet represents one week, as their number would imply, then each "day" is represented by two lines. Fletcher stretches his sequence to cover the year by adding four extra lines to his twenty-fifth sonnet, giving us 366 "days." One could argue that the extra day, possibly like Petrarch's 366th poem in his Rime, launches the poetry away from the sun's orbit into eternity itself, but I think a neater explanation may be found in the fact that 1592 was a leap year.

If each sonnet is in effect a week, then the week in which time is stretched, so to speak, might in some way be special, and indeed it is. Fletcher did not put his extra lines in the absolute centre of his sequence, probably because that particular symmetry would not mean very much if his year began on January 1 ( $\mathrm{I}$ have tried reading the sonnets as starting on March 25 and even on December 12 of the previous year, like some sixteenth-century almanacs, but neither approach can account for the pattern of references to heat and seasons which I will describe shortly). He might have expanded the sonnet containing St. Barnaby's day, the summer solstice as it was reckoned then. Perhaps compromising between St. Barnaby and the sequence's centre while at the same time choosing an ancient holiday connected with the sun, Fletcher attached his four lines to the week containing St. John's Day, Midsummer Day. And whatever its position a little too late for the solstice and a little too early for enthronement in the middle, the sonnet helps indicate Fletcher's structure and the significance of the lady:

Seven are the lights, that wander in the skies, And at these seven, I wonder in my love,

To see the Moone, how pale she doeth arise, Standing amaz'd, as though she durst not move:

So is my sweet, much paler than the snowe, Constant her lookes, those lookes that cannot change, Mercurie the next, a god sweet tong'd we know, But her sweet voice, doth woonders speake more strange:

The rising Sunne doeth boast him of his pride, And yet my love is farre more faire than he.

The warlike Mars, can weildles weapons guide, But yet that god, is farre more weake than she.

The lovelie Venus, seemeth to be faire,

But at her best, my love is farre more bright;

Saturne for age, with groans doth dimme the aire;

Whereas my love, with smiles doth give it light.

Gaze at her browes, where heaven ingrafted is:

Then sigh, and sweare, there is no heaven but this. 
This sonnet, the first in the sequence so explicitly cosmological, offers some interesting features aside from its extra lines. Primarily, of course, it further reveals Licia as the summation of those lights by which we measure change yet in whose wanderings we find order and influence. Unlike Angerianus, moreover, from whom the conceit is taken, Fletcher manoeuvres his lines so as to put the sun and the lady together in the centre of his poem (by a happy accident the lines fall on the modern solstice). ${ }^{3}$ He also expands the material on the moon; perhaps he had noticed that by the end of this poem his sequence had accumulated 354 lines - the number of days in the synodic lunar year.

It is possible that Fletcher is playing with other numbers too, although here the imagination has fewer checks in the text itself and may rapidly leave common sense behind. Thus Licia seems particularly radiant in no. 15 , able to burn her lover so he may rise "Phaenix like," and according to Augustine "fifteen" signifies, among other things, the steps to the Temple and the resurrection when the cycles of time are over. ${ }^{4}$ (But perhaps these reverberations are less appropriate here than in Spenser's poetry, where love is tied to the liturgical as well as the astronomical year.) Fletcher's sonnet 28 - as far beyond the sequence's centre as no. 25 is before it - meditates on time:

In tyme the strong and statelie turrets fall,

In tyme the Rose, and silver Lillies die,

In tyme the Monarchs captives are and thrall,

In tyme the sea, and rivers are made drie:...

Thus all (sweet faire) in tyme must have an end:

Except thy beautie, vertues, and thy friend.

"Twenty-eight," a "perfect" number symbolizing virtue, among other things, is one of those like "fifteen" which can be arranged into an equilateral pyramid; here the pyramid is probably subject to the fate of the turrets and roses but the virtue, we are told, will remain. Licia's true temple is in the heavens. The digressive sonnet to Lady Molineux's children divides the sequence into groups of forty and twelve. These are two very powerful numbers, but I cannot see their relevance here. Has the lover served out his Lenten fast? wandered long enough in the desert of her refusal? Has she resisted temptation for forty days or weeks? Could the "twelve" which follow remind us of months and hours?

In any event the major architecture of the weeks and days is quite clear and to make sure the reader does not miss his game with love and time Fletcher not only numbers his sonnets and refers at the outset to his "daily" hymns but begins his thirty-second sonnet (one of those for 
which there is no source) by saying wearily, "Yeares, months, daies, houres, in sighes I sadlie spend."

That Licia is indeed a "heavenlie woonder," not simply subject to time like her lover but in a sense at one with it and participating in its energies, is seen in this fairly simple numerical structure and also in related patterns involving the sun, temperature, and the seasons.

Licia radiates with references to Phoebus, and almost always these solar images specifically describe the lady herself, the lover's "Bright matchles starre." Like the beloved, furthermore, the sun changes his aspect. Thus in the first sonnet Phoebus the lord of poetry rejects the lover and in the second, after Cupid (as in a number of Anacreontic poems) has managed to confuse the indignant lady with his mother, Licia frowns "like Phoebus in a cloude." These sonnets would correspond to early January. In April, June, and July, however, the sun brightens considerably and Licia sometimes even more so. Thus in no. 15 she shines "Fairer then Phoebus," in no. 23 she could outburn him if she cared to, in no. 25 she is still fairer than the sun, in no. 29 she appears like a "Princely light" in the darkness of the lover's sleep, and in no. 31 "The Sunne doeth shine for joye when as she speakes." By no. 39 (the week of September 25), however, Phoebus is less reliably brilliant and Licia herself seems to slip further away from her lover:

Disperse those clouds, that darkened have my rest:

And let your heaven, a sun-like smile but give.

Then shall I praise, that heaven for such a sunne,

That saved my life, when as my griefe begun.

In no. 43 , to be sure, the sun and moon still shine, but Licia is in eclipse or has disappeared:

Are those two starres, her eyes, my lifes light gone?

By which my soule was freed from all darke....

Whose smyling light did ease my sadde distresse

And broke the clowdes when teares like rayne begun.

Several "weeks" later (no. 45) Licia's eyes shine like a new comet, although far in the Occident, and the lover now hopes that "never after, soule shall live in darke,/That hath the hap, this westerne Sunne to marke." But in no. 47 he is once more alone and hence cannot even write poetry:

So I (my love) inlightned with your shyne,

A Poets skill within my soule I shroud ...

But when your figure, and your shape is gone,

I speechlesse am, lyke as I was before .... 
Towards the end of the sequence (no. 51) there is a brief reference to Licia as "the Sunne, whome all my senses serve" but the very last lines of the "calendar," al though not unhappy, imply that Licia is not immediately present:

Nowe if you aske where dwelleth all this blisse,

Seeke out my love, and she will shew you this.

Licia's sun, in other words, begins the sequence reluctant and clouded and then blazes fiercely and joyfully; but towards the end we hear less of his power and the lady's own presence seems to flicker. As does the year itself, the fifty-two sonnets close with a diminished light, although also with celebration and some hope.

Like the sun and the world he shines upon, Licia changes temperature. Early in the sequence Cupid himself reports that she is "most hard, most cold, made of delayes... She hath no heat, although she living seeme" (no. 3). In no. 4 a kiss from her turns Cupid to ice, and although it is true that in no. 7 her eyes burn, in no. 8 she is harder than flint or the winter's frost. Then Spring arrives. At first it seems to make little difference to flinty, frosty Licia, but by Lady Day (the first of the year according to one way of reckoning) "Inamour'd Jove" orders Cupid to make her love. Cupid replies that this is impossible because "she wanted heate" and in terror at Jove's fury he flees inside Licia where, in a place of such "grace and honour," he is quite safe (no. 13).

In this little narrative we hear only that Licia is still chilly, but allegorically, of course, she now contains Love, so it is not surprising that until the end of "summer" she is no longer hard and cold but hot and indeed dangerously so. Thus in no. 15 she can burn her lover, in no. 19 she sentences him to the fire, and in no. 27 "She toucht the water, and it burnt with love." Later in July Cupid says that on their travels he and Licia have inflamed much of the world:

Both poles we burnt, whereon the world doeth turne,

The rownd of heaven, from earth unto the skies:

And nowe the seas we both intend to burne:

I with my bowe, and Licia with her eyes (no. 30).

In August Licia is still incandescent and inflammatory: no. 33 tells how at a word from her both the lover and his manuscript turned to ashes and in no. 34 we hear that "her lookes, colde yce into a flame can turne."

Eventually Licia cools. In nos. 41 and 42 the lover is still so hot he would burn the Styx and leave Charon stranded, but Licia is so cold she would freeze the dark river and stop the ferry; evidently Charon must allow them to journey into death together. Although the rest of the 
sequence tells us less about Licia's inner weather than had the first and middle parts, and indeed in every respect the final section of the "calendar" is less clear, we certainly never hear again of her warmth and we do have, in this pair of sonnets, evidence that her temperature has dropped again after its spring and summer elevation.

On occasion Fletcher indicates the seasons as they pass. If there are few if any of these references in the early sonnets, at least the speaker tells us of nothing pleasant or verdant in the first few "weeks." In no. 11 (the week of the Spring equinox) we move to the vale which saw the judgement of Paris - the first reference to an unmistakably amiable setting - where inevitably we see Licia surpass the other goddesses, and in no. 12 we hear of wind and storms (it is still March, after all). By no. 14 the world is getting warmer, for Licia "lay sleeping, where birdes musicke made"; the heat, we are told, is great but the shade even greater. In no. 20 Licia once more listens to birds chirping, in no. 26 the lover tells how he lives in a grove with birds, "the gentle winde" and delicious flowers - he invites Licia to join him - and in the next sonnet it must be fairly warm for Licia goes swimming (creating quite a sight, for "the fountaine smoak'd as if it thought to burne").

Once more, though, the end of the sequence has a different tone. Gone are the hot suns (although Phoebus shines from time to time), warm days, birds, and flowers. We do, however, hear once more of winds and rain (no. 36). Since the equinox itself does not come until the next sonnet, it might be thought this is a bit early for such bad weather, but a curious parallel to the actual year 1592 can be found. If we count by weeks, no. 36 (which, interestingly, has no known source) begins on Sept. 4. Now, both Camden and Stow report that very early September brought extraordinarily strong winds which seemed to chase the water right out of the Thames; Camden remarks that they were possibly caused by the approach of the equinox. ${ }^{5}$ I suspect that when Fletcher wrote, "Heare how my sighes, are ecchoed of the wind," he had these memorable winds in mind, although of course the historical reality of his September gusts matters even less than the reality of "Licia" herself.

There is one further piece of evidence that Fletcher quite consciously intended his sonnets to rotate through the year, warming and cooling with the seasons and frequently reminding us of the sun which in large part causes our weather and measures our time yet whose radiance dims before Licia's own. As I have mentioned, Fletcher translated most of his sonnets from Neo-Latin continental poets. ${ }^{6}$ I have compared each of these adaptations with its source and so far as I can make out many of Fletcher's changes seem designed to make his versions fit the patterns I have described. For some reason the sonnets toward the end, mostly from Gruterus, are quite close to the originals. The opening unnumbered 
poem to Licia, however, and many of the remaining poems are quite free. I will mention some of the more significant deviations.

Gruterus' poem on his temple to "Harmosyne," for example, is less precise about "daily" songs, in no. 2, from Angerianus, the explicit mention of Phoebus is not in the original, and in no. 3 Angerianus had made Cupid complain that "haec dura, superba, ferox" but Fletcher says that Licia is cold and "made of delayes." In no. 4 he adds that Licia turned Love to ice, and in no. 9 where Angerianus has a reference to "ignibus" Fletcher cools the poem and Licia to the February weather I think he wanted. He adds storms and winds to the sonnet (no. 12) falling on the week of March 18. For no. 14 he adds the springlike birdsong and in the next the bit about Phoebus is his own. In no. 24, to be sure, Fletcher omits the name of Phoebus, but he omits those of all the other deities as well. In the lengthened sonnet, as I have said, Fletcher rearranges the lines so as to put the sun in the middle (Angerianus has Mars). In the next Angerianus is not only saddened by his beloved's absence but complains that is is cold without her, a detail Fletcher omits (for with or without Licia it is late June). Angerianus says his mistress's talk makes the stars shine and grass grow, which Fletcher in no. 31 changes to "The Sunne doeth shine for joye when as she speakes." No. 45, from Bonnefons, and no. 51, from Ronsard, both have references to the sun not in the originals. Fletcher, then, increases the solar references and through additions or deletions arranges the weather to suit the season.

Fletcher tells Licia in his opening poem that he will build her a temple. But what has a calendar to do with a building? Fletcher was not alone, of course, in raising a temple to his lady, and indeed his opening poem merely adapts Gruterus. Desportes vows to build a temple to his "fiere deesse" complete with his eyes as lamps, body as altar, sighs as vows and heart as sacrifice. Spenser, too, will sacrifice his heart in that fair temple built within his mind. ${ }^{7}$ To conceive of poetry as architecture is not, of course, inherently silly, for both verse and temples are, if rightly constructed, made according to proportion and number. It is true that Time, in a fallen world, moves to somewhat uneven measures - limping a little as he mows - for Phoebus himself slows and quickens his horses' pace; Spenser plays brilliantly with such imperfections in the Epithalamion's numerical ordering. Nevertheless it is possible to associate temporal divisions with temples and indeed it seems likely both Fletcher and Spenser knew of a famous building in which such an association was made.

Daniel Rogers, a prolific if unpublished author of Neo-Latin verse who knew Spenser and probably had friends in common with Fletcher, wrote an epigram on Salisbury Cathedral which his good friend Camden included in Britannia (1586), a work well known to Spenser, who used 
it for The Faerie Queene, and which Fletcher, I imagine, may have read as background for his projected Latin history of Elizabeth's reign:

Mira canam, Soles quot continet annus in una

Tam numerosa, ferunt, aede, fenestra micat.

Marmoreasque capit fusas tot $a b$ arte columnas,

Comprensas horas quot vagus annus habet.

Totque patent portae, quot mensibus annus abundat,

Res mira, at vera res celebrata fide (sig. $\left.13^{\mathrm{V}}\right)$.

Philemon Holland's translation for the English edition reads,

Wonders to tell: How many daies in one whole yeere there beene,

So many windows in one Church (men say) are to be seene.

So many pillars cast by Art, of marble there appeere,

As houres doe flit and flie away throughout the running yeere.

So many gates doe entry give, as monthes one yeere doe make,

A thing well knowen for truth though most it for a wonder take

$\left(1610\right.$, sig. $\left.\mathrm{X}^{\mathrm{v}}\right)$.

Sir John Harington knew either the epigram or the rumour, for he wrote a poem which begins with the same information, although he adds the weeks:

Faire Sarum's Church, beside the stately tower,

Hath many things in number aptly sorted,

Answering the yeere, the month, weeke, day \& houre,

But above all (as I have heard reported,

And to the view doth probably appeare)

A piller for each houre in all the yeere....8

Licia's temple may serve a fictitious deity, but it shares with the cathedral (and according to legend more secular buildings like Knole) a shape both numerical and calendrical.

What will eventually happen to the lover in his temple to Licia is not certain. She is cold again toward the close, less evidently on the scene, and in no. 38, like the September sun itself (the sonnet falls on the modern equinox) she has returned to her dilatory habits: "my soveraigne made a pause,/Dispos'd to graunt, but willing to delay." The ending is not despair, but there is no assured victory. Perhaps, so long as the lover aches for a goddess bound to the circle of the sun, there never can be suns that rise must set again.

It is, I think, in the additional poems that a solution is suggested, for they seem to point away from the inevitabilities of the yearly cycle. Once again Fletcher is playing with time and number, although I am far less sure how he means us to count or interpret. 
To his sonnets, but still under the title Licia, Fletcher adds an ode on the lovers' quarrel and reconciliation; a dialogue between two sea nymphs translated from Lucian by way of Secundus; a Latin distich by Marullus telling us the author was lascivious in song, chaste in mind; a ridiculously paradoxical "lover's maze"; and three elegies for which there is no known source. ${ }^{9}$ The first, on kissing and separation, is four stanzas of six lines each; the second, on the same topic, has six numbered stanzas of six lines each; the third has twelve stanzas of what should be four lines each - thus carrying the progression to 48 . This third elegy, like the second, has numbered stanzas, but the last one is not only unnumbered but incomplete - it has two lines. The poetry itself explains what this is all about. The lover has been complaining that his anguish does no good; the heavens have resolved that the "greatest joyes are temperd with delay." Frustrated, his thoughts "thinke the time too long," but though the sun may freeze and ice may burn, time will never force his "loving thoughtes to turne." He begs that she too will be constant. Many other people, he tells her, live in hope that time will bring ease:

11) If these by hope doe joye in their distresse, And constant are, in hope to conquer tyme, Then let not hope in us (sweete friend) be lesse, And cause our love to wither in the Pryme.

Let us conspyre, and time will have an end, So both of us in time shall have a frend.

In other words Fletcher asks that the lovers look to the future with hope but he also seems to want Time to be cut off at some point, to be so conquered by constancy that love may be friends with it and not, one assumes, subject to decay and decline. In place of the annual round, then, Fletcher offers his Licia love and escape from repetition, from moving to June only to confront September. In the sonnets he had said confidently that despite her illness she was immortal and he had seen in her comet-like radiance some permanent comfort; but the pattern of the sequence gives the lie to these hopes. The last elegy stops time - the twelfth stanza halts before the day (or perhaps December) can end. Fletcher's refusal to finish his poem in some ways parallels Spenser's ending of the Epithalamion, except that what for Spenser was to be a subtle comment on mutability and marriage here seems to attempt an end run around time. The last line is ambiguous. Does the lover mean "one day each of us will have a friend" or "each of us will make friends with time"? In any event in the additional poems the lover hopes to win joy through a constancy which will bring time - or one sort of 
time - to an end. Nor, in these additional poems, does he associate Licia with the sun. She is less solar and more accessible.

In these poems Fletcher seems once more to be playing with numbers, although he possibly intended us to count his verse in more than one way. If we count the Latin distich - not by Fletcher and in a different language - then we have seven additional poems, which is a good number to have in a collection so time-obsessed. In that case we have 362 lines. This figure has no particular significance I know of, but perhaps we can legitimately make some interesting additions or subtractions. If we add the two "missing" lines at the end of Licia we would have 364 lines, or one day short of the year (unless we count "Finis," which seems too desperate). Could Fletcher have meant his 364 to balance the 366 of the sonnets' "days"? The number is also the total of the weeks times the days, a nice pair of factors in a work like this.

Fletcher indicates the truncation of time in his last stanza, however, and has no urgent need of a year stopping just short of its conclusion. Perhaps, then, he did not mean us to count the distich; it could be an interruption, like the sonnet to Lady Molineux's children. In this case we would have six poems - the marriage number - and 360 lines, or the degrees in the celestial circle. The perfection of this circle seems to stress the lover's hope of time's end (as completion, if not as cessation). The 360 degrees imply a timelessness and eternity the actual sun cannot achieve as he makes his way through the 359 degrees of his daily rotation and brings the changing seasons of the year. But Fletcher may mean us to see both patterns: the year which he halts before its completion and the circle. Each in its way suggests a relationship to time in which the constant lover may be united with his Licia and with whatever earthly or heavenly wonder she represents.

\section{Barnard College}

\section{Notes}

1 "A Numerical Key for Spenser's Amoretti and Guyon in the House of Mammon," The Yearbook of English Studies 3 (1973), 14-27. For this article I have also made use of his Short Time's Endless Monument (New York, 1960) and Alastair Fowler, Triumphal Forms (Cambridge, 1970).

2 The English Works of Giles Fletcher, the Elder, ed. Lloyd E. Berry (Madison, Wisc., 1964), p. 56. All of my quotations are from this edition. Berry's notes indicate Fletcher's sources.

3 For some reason Jupiter is missing here, although Angerianus includes him.

4 Opera omnia (Paris, 1841), IV, 1960, 1144; VI, 749-50. See also Petrus Bongus, Numerorum mysteria (Bergamo, 1591 ed.), sigs. $\mathrm{Cc1}^{\mathrm{V}}-\mathrm{Cc}^{\mathrm{v}}$. 
5 John Stow, Annales (1631), sig. Sss4; William Camden, Annals, tr. R. Norton (1635 ed.), sig. $\mathrm{Mm} 2^{\mathrm{V}}$.

6 See Berry's notes. I think, however, that no. 5 is not from Angerianus' "De Caelia, api, et Amore" but rather from his "Ad Caeliam" on the same page.

7 Desportes, Amours de Diane I no. 43; Spenser, Amoretti no. 22. Cf. the opening of Virgil's third Georgic, in which the poet proposes to build a poetical temple for Augustus.

8 The Epigrams of Sir John Harington, ed. Norman E. McLure (Philadelphia, 1926), no. 290. On Rogers see James E. Phillips, "Daniel Rogers: A Neo-Latin Link Between the Pléiade and Sidney's 'Areopagus" in Neo-Latin Poetry of the Sixteenth and Seventeenth Centuries (William Andrews Clark Memorial Library, University of California, Los Angeles, 1965). I have no evidence that Fletcher knew Rogers, although both were involved in diplomatic affairs. Fletcher's years at Cambridge, incidentally, overlapped those of Spenser, Harington, and Gruterus.

9 This is not to say that Fletcher's verse here is strikingly personal or original; most of his conceits have ample precedent in the work of the Neo-Latin poets, the Pléiade, and Desportes. Perhaps Fletcher knew Desportes' "Pour le premier jour de l'an" in Diverses amours (ed. Victor Graham, Geneva, 1963), which in twelve quatrains compares the lover's constantly renewed suffering to the perpetually regenerating year, or the numerically more complex "Le cours de l'an," itself from Stefano Santini, in Les amours d'Hippolyte (ed. V. Graham, Geneva, 1960), which makes the same point while playing with 4, 12, and 52. Unlike Giles Durant and Chapman in their amorous zodiacs, Desportes stresses the similarity of the year's repetitions to the lover's futile anguish. 